\title{
Pendekatan Multikultural MENUJU PEMAHAMAN AGAMA YANG PLURAL
}

\author{
Oleh M. Zainuddin*
}

\begin{abstract}
Abstrak
Kita masih memiliki harapan akan lahimya perubahan yang menggembirakan. Di kalangan akademisi dan intelektual kita, kini telah muncul "kesadaran baru" bagi tumbuh dan berkembangnya pemikiran terbuka (inklusif) dalam pemahaman agama. Munculnya pemikiran intelektual Islam transformatif, liberal, inklusif. kontekstual, dan apa pun istilahny: merupakan era baru bagi desakralisasi pemikiran Islam (alla taqdisiylah). Apalagi kemudian pemikiran-penikiran kontemporer liberal-inklusif seperti Hassan Hanafi, Arkoun, al-Jabiri, al-Naim dan seterusnya telah disosialisasikan oleh generasi intelektual muda di Indonesia.
\end{abstract}

Kata Kunci; Pendekatan Multikultural, Agama, Plural

\section{A. Pendahuluan}

Kritik terhadap agama (baca: produk pemikiran Islam) oleh sebagian besar umat Islam selama ini masih dianggap tabu dan tidak niscaya. Padahal yang disebutsebut sebagai agama selama ini tidak lain adalah produk pemikiran ulama' atau manusia yang tidak luput dari khilaf, ikhtilaf (debatable) dan sebagian besar masih memerlukan reinterpretasi dan reaktualisasi.

Pembakuan atau pensakralan pemikiran ajaran agama (tagdis al-afkar aldiniyyah) inilah yang selama ini terus dipertahankan oleh sebagian besar umat Islam, termasuk umat non. islam. Sehingga klaim-klaim kebenaran (truth claim) terhadap ajaran agama menjadi tak terelakkan. Klaim-klaim kebenaran ini pada gilirannya melahirkan eksklusivisme dan absolutisme. Ini tentu menjadi problem tersendiri -untuk tidak menyebut berbahaya- bagi keberlangsungan masa depan agama-agama di dunia, artinya bahwa sikap-sikap keberagamaan tersebut akan membawa dampak atau konflik agama (baik antar umat beragama maupun intern umat beragama) ke depan, dan semakin menjauhkan nilai-nilai persaudaraan dan

* Penulis adalah Pembantu Dekan I Fakultas Tarbiyah UIN Malang, sedang menyelesaikan studinya S-3-nya di IAIN Sunan Ampel Surabaya 
kedamaian yang sesungguhnya inheren secara konseptual dalam agama itu sendiri. Kasus pengkafiran oleh sekelompok umat Islam terhadap Ulil Abshar Abdalla karena pemikiran liberal-nya, merupakan fenomana yang memprihatinkan dalam konteks relasi antar umat beragama maupun intern umat beragama, Demikian pula kasus kekerasan yang bernuansa agama, termasuk religion terorism yang menjadi isu sentral sekarang ini juga tak luput dari problem di atas.

Acapkali orang menganggap pendapatnya sebagai satu-satunya yang benar, sementara yang lain salah. Konsekuensi dari anggapan ini kemudian melebar sampai kepada claim kebenarannya (truth claim) terhadap persoalan agama. Padahal apa yang dianggap sebagai "agama" itu tidak lain adalah penafsiran terhadap agama itu sendiri.

Kita memang sepakat bahwa agama (baca:Islam) memiliki kebenaran yang absolut, mutlak. Konsekuensi dari keyakinan ini kemudian kita wajib mengikuti ajaran agama tersebut. Hanya persoalannya, aspek manakah agama yang dianggap sebagai memiliki kebenaran mutlak itu? Seberapa banyak porsi ajaran absolut dalam agama itu?

Kebanyakan ulama' berpendapat, bahwa absolutisitas agama ada pada wilayah ijma' ulama', atau pada wilayah dalil mulkamat, seperti: tentang keesaan Tuhan, kebenaran al-Qur'an dan kebenaran perintah shalat dst. Sementara pada wilayah dalil musytarak dan mutasyabihat yang masih menjadi ikhtilaf ulama' (karena perbedaan penafsiran, interpretasi), maka bersifat relatif. Tetapi yang perlu dicatat, bahwa relativitas dimaksud adalah relativitas dalam konteks kebenaran, bukan dalam konteks salah dan keliru. Karena Tuhan memberikan jaminan kepada ulama'/ mujtahid yang melakukan upaya istinbath hukum, yaitu jaminan kebenaran (Izajtahad al-hakim fa ashaba falahu ajrani wa iza akhtha'a falahu ajrun wahid).

Pertanyaan yang mungkin muncul lagi, adakah ijma' ulama' itu? Dalam khazanah Ushul Fiqh ijma' ulama' itu memang ada, hanya porsinya sangat sedikit dan terbatas. Hal ini sejalan dengan absolutisitas ajaran agama itu sendiri. Dengan demikian, yang perlu dipahami adalah, bahwa relativitas dalam ajaran agama itu sangat dominan. Al-Qur' an memang memberikan porsi "berbeda pendapat", porsi ber-ijtihad lebih banyak ketimbang porsi untuk ijma'. Apa hikmahnya? Supaya umat Islam kreatif dan dinamis. Sebab kondisi dan setting sosial setiap kurun memiliki perbedaan sesuai dengan wilayah di mana mereka tinggal. Itulah yang kemudian melahirkan - menggunakan istilah Abdalla "wama-warni" Islam: ada Islam Arab, ada Islam Persi, Islạm Indonesia dan seterusnya. Ada hukum Islam 'ala al-mazahib al-arba'ah, ada qaul qadim dan qaul jadid Imam As-Syafi'i dan seterusnya. Ini pulalah yang kemudian melahirkan pluralitas umat, firqah-firqah dan jama'ahjama'ah dalam Islam, dan pluralitas itu sendiri merupakan sunnatullah. Tetapi yang perlu dipahami, bahwa wama-wami Islam itu secara substansial tidak memiliki 
perbedaan. Hanya sayang, selama ini yang terjadi justru perbedaan itu dipahami sebagai sesuatu yang aneh sehingga melahirkan pertentangan dan permusuhan, bahkan sampai pada konflik yang memprihatinkan. Padahal Nabi sendiri menegaskan, bahwa ikhtilaf yang ada pada umatnya sebagai sesuatu yang membawa rahmat.

Para ulama' sepakat bahwa sumber yang memiliki kebenaran yang mutlak adalah al-Qur' an dan Hadis mutawatir. Hanya yang perlu diketahui, bahwa dalam Hadis pun yang dianggap mutawatir itu amat sedikit jumlahnya. Bahkan Imam AsSyatibi berpendapat, bahwa sedikit sekali, bahkan hampir dikatakan tidak ada satu teks keagamaan baik yang ada dalam al-Qur'an maupun al-Hadis yang secara berdiri sendiri memiliki interpretasi tunggal, sehingga menjadikan ia absolut.

\section{B. Klaim Absolutisme Agama-Agama}

Klaim absolutisme, sebagaimanạ yang diungkap oleh John Hick, (1985: 46), dilakukan oleh agama satu terhadap agama lain. Dan klaim tersebut berlaku bagi semua agama, baik Islam, Kristen Hindu maupun Yahudi. Dalam tradisi Hindu misalnya, seorang Hindu mempercayai bahwa seseorang dapat mencapai sanata Dharma, kebenaran eternal, yang menjelma dalam bahasa manusia sebagaimana yang disebutkan dalam kitab Veda. Ada toleransi umum yang terkait dengan anggapan, "bahwa cepat atau lambat setiap orang pada waktunya akan memasuki atau mengalami kesempatan memahami Veda". Dalam pandangan filsafat advaitic dinyatakan, bahwa bentuk teistik agama merepresentasikan sekurang-kurangnya keasadaran yang tinggi tentang realitas Agung.

Menurut Hick (1985: 48), Hinduisme adalah kesadaran —sekurang-kurangnya bagi banyak pengikutnya - dan keunggulan khusus diantara gerakan-gerakan keagamaan dunia, dan kesadaran semacam itu menurut Hick, secara alamiah tidak medorong penerimaan sebuah keaslian pluralisme agama.

Sebagaimana analisis Coward (1989:144), bahwa agama Hindu memandang agama-agama lain sebagai wahyu Tuhan dan sebagai penyediaan jalan berbeda yang dengannya kaum beriman dapat mencapai pembebasan dari karma-samsaranya. Hindu melihat dirinya sebagai agama yang sangat terbuka dan toleran. Namun karena agama Hindu menegaskan bahwa Veda merupakan wahyu yang paling sempurna dari kebenaran ilahi, maka agama Hindu juga melihat dirinya sebagai pemberi kriteria yang harus digunakan sebagai dasar untuk menguji wahyu-wahyu dari semua agama lainnya. Dengan demikian menurut Coward (1989: 144), toleransi Hindu terhadap agama-agama lain langsung sebanding dengan keselarasan agamaagama itu dengan Veda. Menurut Hindu, hanya ada satu wahyu (yang terdapat dalam Veda), selainnya (Taurat, Perjanjian Baru, atau al-Qur'an) dilihat sebagai perwujudan kedua yang harus diuji dengan menggunakan wahyu Hindu. Inilah yang 
menurut Coward, toleransi Hindu terbatas, atau ada batasnya. Orang-orang Hindu tidak berbeda dengan pemeluk agama-agama lain yang meyakini bahwa mereka memiliki wahyu yang benar dan berusaha memaksakan kebenaran (truth claim) kepada orang lain. Di sinilah persoalan klaim kebenaran dan keaslian itu berlaku bagi semua agama.

Sebagaimana keterangan Hick (1985: 48), klaim absolutisme agama bagi orangorang Yahudi adalah, bahwa mereka mengaku sebagai umat atau "manusia pilihan Tuhan", sebagai perantara Tuhan untuk menyampaikan wahyu kepada semua manusia. Untuk menjadi Yahudi, orang harus mempunyai hubungan khusus dengan Tuhan.

Agama Budha mengklaim, bahwa penghargaan yang sesungguhnya mengenai keberadaan manusia terjadi sebagian besar dan efektif dalam ajaran Budha Gautama. Menurut Budha, Dharma adalah yang memelihara kebenaran penuh, penjelasan yang khusus dan efektifserta akhirdiantara illuminasi dan wahyu tentang dunia.

Dalam agama Islam ada kepercayaan tegas bahwa Muhammad adalah Nabi dan melalui al-Qur'an Tuhan telah mewahyukan kepada manusia akan kebenaran agama itu. Bahwa agama yang paling benar adalah Islam, segala penyembahan harus kepada Allah, selain-Nya adalah syirik.

Dalam kepercayaan Kristen, Yesus Kristus adalah peletak dasar dan pusat agama, Dia juga Tuhan dalam bentuk manusia. Dogma ini merupakan konsekuensi sejarah yang alami bagi orang-orang Krsiten yang menganggap agama mereka sebagai satu-satunya agama yang benar, yang dibangun oleh Tuhan dalam dirinya dan akibat dari itu adalah bahwa semuanya menempuh jalan menuju Tuhan. Dari sinilah kemudian timbul perintah untuk mengajak semua orang bersedia menerima agama Kristen serta menjadi anggota gereja. Masing-masing dari tradisi agama besar dengan demikian menempuh satu jalan atau jalan lain yang memiliki kelebihan khusus.

Katolik tradisional, sebagaimana kata Hans Kung (1998:11), juga memiliki posisi yang tidak plural, mereka menyatakan: "Tak ada keselamatan di luar Gereja". Gereja suci Roma tegas-tegas meyakini, bahwa tak seorang pun di luar gereja Katolik, baik orang kafir atau Yahudi atau orang yang tidak beriman, tidak juga orang yang terpisah dari Gereja akan ikut bersama-sama dalam kehidupan yang kekal, tetapi akan binasa dalam api kekal yang disediakan untuk syetan dan anak cucunya jika orang-orang tersebut tidak tergabung dengan gereja Katolik sebelum mati. Klaim-klaim kebenaran seperti ini menurut Kung sudah berjalan selama lebih dari 1200 tahun.

Seperti yang dikatakan Mary Ann Stenger (lihat Thomas Dean, ed., 1985: 92), bahwa John Hick menggunakan perbandingan lintas budaya (crooss-cultural) mengenai ide-ide dan penampilan agama-agama untuk meyakinkan kepada Kristen 
Barat, bahwa mereka harus terbuka terhadap kebenaran agama di luar tradisinya. Hick berpandangan bahwa ada satu Tuhan tak terbatas (Maha Kuasa) yang ada di balik semua kesan dan pandangan agama yang berbeda. Oleh sebab itu menurut Hick, tidak beralasan bagi suatu agama yang mengklaim dirinya paling benar dan menganggap agama yang lain salah. Adalah tidak mungkin bahwa kesan paling lengkap atau kurang lengkap tentang Tuhan dilakukan dalam tradisi keagamaan yang berbeda. Dalam karyanya, On Grading Religions (h. 467), Hick berusaha menilai agama-agama itu sebagai tradisi-tradisi yang utuh, (total) ketimbang melihatnya sebagai fenomena keagamaan yang partikular dan pada akhirnya merupakan kerja yang tidak realistik. Hick melihat tradisi perbedaan keagamaan dianggap sebagai sama-sama produktif (equally-productive) dalam mengubah manusia dari perhatian pada diri sendiri (Self-Centredness, istilah yang dipakai Tracy) menuju perhatian pada Tuhan (Reality-Centredness). Hick dalam hal ini menganalisis kriteria dan pendekatan-pendekatan evauluatif yang mungkin dapat membantu dalam menilai kultur keagamaan secara lengkap dan utuh (lihat juga Hick, 1985: 53).

Hick menganalisis tiga kriteria ketika orang menyambut dan menerima perantara Tuhan dalam membangun sebuah tradisi keagamaan. Pertama, adalah krieteria moral yang didasarkan pada sebuah tatanan moral universal, yang mempertanyakan: Apakah perantara (mediator) itu lebih baik dari kejahatan, dan apakah ajarannya menawarkan sebuah visi moral lebih baik dari pada moralitas umum yang ada? Kedua, kriteria yang menfokuskan pada kemampuan mediator untuk mengungkapkan visi baru tentang realitas yang mendorong manusia untuk mengikutinya: Apakah visi baru itu lebih baik, dan apakah kehidupan baru dan lebih baik itu bisa melalui mediator tersebut? Ketiga, kriteria yang memusatkan pada respon manusia: Apakah manusia bisa berubah dan dijamin bahwa Tuhan kenyataannya mengantarkan mereka?

Hick mengajukan evaluasi rasional mengenai kognisi, elemen-elemen teori mengenai tradisi keagamaan dan evaluasi moral tentang aktualisasi kultur-sejarah kepercayaan keagamaan. Namun menurut penilaian Stenger (lihad Dean, ed., 1985. 93), keduanya (baik evaluasi rasional maupun moral) mengarah pada kesimpulan positif dan negatif, lebih kuat dan lebih lemah yang memberi contoh setiap tradisi. Orang boleh juga mempertanyakan, apakah visi dasar keagamaan berlanjut menjadi efektif secara "soteriologic" (soteriologically effective) atau hidup yang transformatif, tetapi akhir pembuktian tentang itu bersifat eskatologis. Pada akhimya — menurut Stenger- Hick tidak menemukan kriteria yang cukup untuk perbandingan yang memadai dan penilaian yang baik terhadap tradisi keagamaan secara utuh. Meski begitu menurut Stenger, kriteria-kriteria yang dibuat Hick itu bisa dipakai pada fenomena keagamaan khusus dan oleh karena itu patut dipertimbangkan dalam persolan yang terkait dengan isu penilaian kebenaran 
keagamaan tersebut.

Menurut David Tracy (1985:89-90), Hick mengatakan bahwa semua cara yang ditempuh agama-agama menuntut transformasi tunggal mengenai diri: dari pemusatan diri (Self-Centredness) menuju pemusatan Tuhan (Reality-Centredness). Dalam beberapa cara keagamaan, orang harus merubah perhatian ego dengan menggunakan hubungan baru dengan Tuhan. Hanya kemudian, dapatkah diri (self) berhenti menjadi ego dan menemukan kebebasan otentik yang dihubungkan dengan alam, sejarah, dan yang lain? Adalah tidak mungkin bahwa semua pencerahan keagamaan berbeda ekspresi dari posisi keagamaan yang sama. Pluralitas diantara agama-agama tidaklah mereduksi terhadap klaim bahwa mereka semua memperlihatkan pencerahan yang sama atau praktik yang sama tentang kebebasan.

Ada kemiripan diantara agama-agama, tetapi sepanjang pengamatan Tracy (1987: 90) diantara agama-agama tersebut tidak ada yang memiliki esensi tunggal, tidak ada muatan tunggal tentang pencerahan atau wahyu, tidak ada cara tunggal tentang. emansipasi atau liberasi yang dibangun dalam semua pluralitas itu. Ada perbedaan penafsiran tentang Tuhan itu sendiri: God, Emptiness, Suchness, the - ne, Nature, the Many. Ada perbedaan pemahaman mengenai apa yang diwahyukan oleh Tuhan tentang Tuhan dan tentang diri kita dalam hubungan kita tentang harmoni dan disharmoni dengan Tuhan tersebut. Ada perbedaan penafsiran tentang cara apa yang harus kita ikuti untuk mengubah (pandangan kita) dari pemusatan-diri secara fatal menuju pemusatan-kepada Tuhan secara bebas. Diskurus dan cara-cara agama seperti itu kadang-kadang bisa saling melengkapi, dan pada batas tertentu, melengkapi beberapa aspek yang belum maju dari yang lain. Agama-agama juga bisa mengganggu dan melenyapkan yang lain.

Menurut Hick (lihat Zakiyuddin, 2002: 20), bahwa pluralisme agama mengimplikasikan pengakuan terhadap fondasi bersama bagi seluruh varitas pencarian agama dan konvergensi agama-agama dunia. Bagi sebagian lainnya, pluralsime agama mengimplikasikan saling menghargai di antara berbagai pandangan dunia (wold-view) dan mengakui sepenuhnya perbedaan tersebut. Jika yang pertama menekankan kebebasan beragama individu, maka yang kedua menekankan pengakuan atas denominasi sebagai pemberi jawaban khas. Hick memang, sebagaimana kata Soroush (2000: 104), adalah seorang teolog yang membela pluralisme dan inklusivisme sejajar dengan Kung, Smart dan Toynbee.

Tetapi, kenapa pula pemeluk agama monoteis justru inheren dengan intoleransi dan kekerasan? Menurut Rodney Stark (2003: 171-173), claim pemeluk agama monoteisme yang partikularistk-subjektif -bahwa agama yang dipeluknya adalah satu-satunya yang benar, yang hanya percaya pada satu Tuhan, Yang Esa dan Sejati (One True God)-banyak memicu konflik. Stark menyoroti subjektivisme para pemeluk agama monoteistik (baik Yahudi, Kristen maupun Islam) yang memandang rendah agama lain. Melalui penelitiannya, Stark berkesimpulan, bahwa 
berbedaan agama dalam seluruh masyarakat berakar pada relung-relung sosial, kelompok-kelompok orang yang saling berbagi preferensi berkaiatan dengan intensitas keagamaan (Stark, 2003: 175). Ketika beberapa agama partikularistik yang kuat saling mengancam antara satu dengan yang lain, maka konflik akan termaksimalisasikan, begitu pula tingkat intoleransi (Stark, 2003: 183).

. Menurut Stark, pluralisme agama memang merupakan keniscayaan dan pluralisme dalam orde sosial dapat menjadi stabil selama dalam organisasi-organisasi keagamaan tidak terdapat satu pun dari padanya yang terlalu kuat. Namun jika sebaliknya yang terjadi, maka sudah dapat dipastikan akan terjadi konflik yang intens (Stark, 2003: 76). Stark sampai pada kesimpulan, bahwa konflik agama akan menjadi memuncak jika beberapa organisasi keagamaan yang kuat dan partikularistik hidup berdampingan (Stark, 2003: 181).

Menurut Armahedi Azhar, terdapat lima penyakit yang menghinggapi para aktivis gerakan keagamaan, yaitu: absolutisme, ekslusivisme, fanatisme, ekstremisme dan agresivisme. Absolutisme adalah kesombongan intelektual, ekslusivisme adalah kesombongan sosial, fanatisme adalah kesombongan emosional, ekstremisme adalah sikap yang berlebihan dan agresivisme adalah tindakan fisik yang berlebihan (lihat Andito, ed., 1998: 15).

Dalam melakukan dialog dengan agama lain, apapun bentuknya, diperlukan adanya sikap saling terbuka, saling menghormati dan kesediaan untuk mendengarkan yang lain (Zebiri, 1997: 37). Sikap-sikap ini diperlukan untuk mencari titik temu (kalimatun saw' ') antara berbagai agama, karena masing-masing agama mempunyai karakteristik yang unik dan kompleks.

Huston Smith, dalam memberikan komentarkarya Schuon mengenai hubungan antara agama-agama, mengatakan bahwa segala sesuatu memiliki persamaan dan sekaligus perbedaan, demikian juga dengan agama. Agama-agama yang hidup di dunia ini disebut "agama" karena masing-masing memiliki persamaan. Persamaan atau titik temu antara agama-agama tersebut berada pada level esoterisme, sedangkan pada level eksoterieme, agama-agama tampak berbeda (Schuon, 1984: xii).

Menurut Raimundo Panikiar, untuk memahami agama-agama orang lain secara komprehensif, kita harus memahami agamanya melalui bahasa aslinya. Kita tidak bisa mengabaikan perbedaan-perbedaan yang ada dalam masing-masing agama untuk menarik kesimpulan bahwa "semua harus menjadi satu". Menurutnya, setiap agama merefleksikan, membenarkan, dan melawan yang lain (Lyden, 1995: 86).

\section{Pendekatan Multikultural: Menuju Umat Yang Harmoni}

Harus diakui, bahwa agama-agama, disamping memiliki klaim absolutisme, 
juga memiliki klaim inklusivisme. Dalam konteks ini ada kasus menarik yang pemah dialami oleh Nabi Muhammad, yaitu ketika kaum musyrik bersikeras menolak ajaran Islam, maka demi kemaslahatan bersama Tuhan memerintahkan kepada Nabi untuk berkata kepada mereka: “....Tuhan kelak akan menghimpun kita semua, kemudian Dia memberi keputusan diantara kita dengan benar. Sesungguhnya Dia Maha Pemberi Keputusan lagi Maha Mengetahui" (perhatikan QS.34:24-26).

Menurut penafsiran Quraish Shihab (1992:222), ketika absolutisitas diantar ke luar (ke dunia nyata), Nabi tidak diperintahkan untuk menyatakan apa yang ada di dalam (keyakinan tentang absolutisitas agama tersebut), tetapi justru sebaliknya. Itulah sebabnya menurut Quraish Shihab, bahwa salah satu kelemahan manusia adalah semangatnya yang menggebu-gebu, sehingga ada di antara mereka yang bersikap melebihi Tuhan, misalnya menginginkan agar seluruh manusia satu pendapat, menjadi satu aliran dan satu agama. Semangat yang menggebu-gebu ini pulalah yang mengantarkan mereka memaksakan pandangan absolutnya untuk dianut orang lain. (Quraish Shihab, 1998: 153).

Pada umumnya kebanyakan filosuf berpendapat bahwa hakikat realitas tertinggi adalah satu, maka secara otomatis prinsip-prinsip filosofis yang digunakan semua agama juga satu. Ketika 'allamah Thabathaba'i berbicara tentang agama pada level filosofis ia tidak pernah bersikap permissif, tetapi ketika kajiannya mulai menyentuh dataran sosiologis ia sangat toleran, begitu pula muridnya, Muthahhari. Itulah sebabnya menurut Shahab, dalam masalah perbandingan agama hendaknya digunakan perspektif filosufis, bukan sosiologis, untuk menghindari pada jebakan simbol-simbol agama.

Brian Fay (1996) dalam mengkaji fenomena sosial menggunakan pendekatan yang disebut dengan pendekatan multikultural. Ada dua belas pendekatan multikultural dalam filsafat ilmu sosial yang dibangun oleh Fay. Pendekatan ini mencoba mendamaikan berbagai perbedaan pandangan dalam ilmu sosial dengan cara yang lebih mendalam, plural, inklusif, tanpa sekat dan subjektivisme.

Dalam filsafat ilmu sosial terdapat pola yang bersifat dualistis yang mendominasi. Pola itu terkait dengan pertanyaan: "Apakah satu pilihan atau pilihan lainnya —dan kemudian salah satu diantaranya dianggap pilihan yang benar?" Fay berusaha menghindari dualisme yang merusak, misalnya: diri vs. orang lain; subjetivisme vs. objektivisme; atomisme vs. holisme; kebudayaan kita vs. kebudayaan mereka; orang dalam vs. orang luar; kesamaan vs. perbedaan dst. Fay menjelaskan tentang "memahami orang lain" dan "mengkritik orang lain". Antara memahami dan mengkritik adalah dua hal yang berbeda. Ilmu sosial terkait dengan usaha memahami orang lain bukannya menilai orang lain.

Dari dua belas tesis filsafat multikultural yang dibangun Fay ini, ada empat poin yang penulis anggap tepat untuk memshsmi pluralisme agama, yaitu: pertama, mewaspadai adanya dikotomi, menghindari dualisme buruk dan berpikir secara 
dialektis. Sebagaimana yang disarankan oleh Fay, kita tidak boleh terjebak pada kategori-kategori yang saling bertolak belakang. Kategori-kategori atau dikotomidikotomi itu harus disikapi secara terbuka dan dipikirkan secara dialektis; keduc, tidak menganggap orang lain sebagai "yang lain". Sebenaranya semua identitas pribadi pada hakikatnya menurut Fay bersifat dialogis. Tidak ada pemahaman diri tanpa pemahaman orang lain, dan jangkauan kesadaran diri kita dibatasi oleh pengetahuan orang lain; ketiga, mentransendensikan kesalahan memilih antara universalisme dan partikularisme, asimilasi dan pemisahan. Hendaknya kita memanfaatkan perbedaan, dengan mengambil hikmah, pembelajaran dan saling menguntungkan; keempar, berpikir secara proses, dengan pengertian kata kerja (proses) bukan kata benda (produk).

Jika umat beragama mampu menggunakan pendekatan multikultural dalam berinteraksi, maka keberadaan agama dan perbedaan yang ada diantara agamaagama tidak akan menimbulkan pertentangan dan konflik yang membahayakan.

Menyangkut masalah pemahaman dan peran agama, secara umum, dapat dilihat dari dua aspek. Pertama adalah aspek konatif (conative aspects). Aspek ini berkaitan dengan kemampuan agama dalam menyediakan sarana kepada masyarakat dan anggota-anggotanya untuk membantu mereka menyelesaikan berbagai persoalan kehidupan. Kedua, aspeknya yang bersifat kognitif (cognitive (.spects). Aspek ini terkait dengan peranan agama dalam menetapkan kerangka makna yang dipakai oleh manusia dalam menafsirkan secara moral berbagai kesukaran dan keberhasilan pribadi mereka: juga sejarah masyarakat mereka di masa yang silam dan keadaannya di masa kini, (Nottingham, 1985:107-108).

Pemahaman terhadap peranan agama semacam itu dapat ditemukan batu pijakannya dalam berbagai sumber suci agama-agama semit. Dalam Islam misalnya, al-Quran tidak hanya mewajibkan kepada umatnya untuk melakukan ibadah-ibadah ritual-seremonial yang bisa memberikan kelegaan emosional dan spiritual, tetapi juga membuka ruang penafsiran intelektual guna membantu manusia dalam mendapatkan makna dari seluruh pengalaman hidupnya. Peranan Islam seperti ini tampak dengan jelas dalam hampir setiap ibadah ritualnya selalu terkandung apa yang biasa disebut dengan pesan moral. Bahkan begitu pentingnya pesan moral ini, "harga" suatu ibadah dalam Islam dinilai dari sejauh mana pesan moralnya bisa dijalankan oleh manusianya. Apabila suatu ibadah tidak bisa meningkatkan moral seseorang, maka ibadahnya dianggap tidak ada maknanya. Oleh karena itu, ketika seseorang melakukan hal-hal yang terlarang secara figh dalam suatu ibadah, maka tebusannya adalah menjalankan pesan moral itu sendiri. Misalnya, pada bulan puasa, sepasang suami istri berhubungan intim pada siang hari, maka kifarat (dendanya) ialah memberi makan enam puluh orang miskin, karena salah satu pesan moral puasa ialah memperhatikan orang-orang yang lapar di sekitarnya.

Aspek kognitif peranan agama semacam ini juga bisa dijumpai dalam agama 
Kristen. Narasi tentang Ayub dalam Bibel misalnya-atau Nabi Ayyub dalam alQuran-merupakan simbol persoalan kemanusiaan yang mengandung ajaran moral sangat dalam. Kesungguhan Ayub dalam menjalankan kewajiban sosial dan keagamaan memang tidak serta merta menjadikannya bahagia, sebaliknya menyebabkan dia memperoleh cobaan penderitaan. Tetapi kesungguhan Ayub dalam menghayati niali-nilai sakral yang terdapat dalam perintah-perintah Tuhan bukan hanya menyebabkan dia bertahan atas penderitaan tersebut, namun juga membantu dia menemukan makna dari seluruh pengalaman hidupnya. Sehingga, ketika Ayub minta keterangan kepada Tuhan tentang apa yang terjadi, bukan keadaan dirinya yang diutamakan tetapi justru nasib buruk yang menimpa seluruh umatnya yang dikedepankan. (Nottingliam, 1995:108-109).

Pesan agama yang terpantul dari kisah tentang Ayub itu adalah, bahwa ketidaksamaan nasibuntung dan malang manusia tidak dapat dijelaskan begitu saja menurut ukuran baik buruk manusiawi, tetapi harus dilihat pula dari segi adanya penilaian-penilaian Tuhan di dalamnya. Di situlah terletak (salah satu) fungsi agama yang penting, yaitu "memberikan makna moral dalam pengalaman-pengalaman kemanusiaan". Makna moral di sini paralel dengan apa yang dikatakan oleh Paul B. Horton dan Chester L. Hunt (1993: 304), bahwa semua agama besar menekankan kebajikan seperti kejujuran dan cinta sesama. Kebajikan seperti ini sangat penting bagi keteraturan perilaku masyarakat manusia, dan agama membantu manusia untuk memandang serius kebajikan seperti itu.

Persoalan makna agama sebagaimana tergambar pada ajaran Islam dan Kristen di atas merupakan persoalan makna agama dalam pengalaman individual. Secara esensial, persoalan yang sama bisa juga ditemukan pada level masyarakat secara keseluruhannya. Persoalan-persoalan seperti ketidakadilan sosial, kesenjanǵan ekonomi, serta persoalan kekuasaan merupakan rahasia umum dalam kehidupan masyarakat manusia. Fenomena semacam ini secara sosiologis sangat bisa mendorong timbulnya penafsiran-penafsiran moral terhadap tertib sosial yang ada. Pada situasi dan kondisi tertentu tidak jarang dapat menimbulkan konflik-konflik sosial, apabila interpretasi yang dilakukan oleh masing-masing anggota masyarakat tidak mencapai titik temunya.

Atas dasar pemahaman seperti itu, persoalan makna agama dalam pengalaman masyarakat menjadi lebih unik dan rumit dibanding pada pengalaman individu. Apabila suatu masyarakat mampu memahami peranan agama dalam membantu menafsirkan secara moral pengalaman hidupnya secara tepat, maka agama akan hadir sebagaimana fungsinya. Sebaliknya, jika mereka salah dalam melakukan interpretasiinterpretasi tersebut maka agama bisa menjadi lahan subur bagi perkembangan konflik di tengah-tengah masyarakat.

Jika agama memang menyumbang perdamaian, maka penganut agama harus belajar meninggalkan absolutisme dan menerima pluralisme, demikian ungkap 
Nurcholish Madjid (1998: 16 I-162). Kita boleh memandang agama sebagai absolut, namun yang harus diingat bahwa pemahaman kita —baik pribadi maupun kelompok - menyimpan kualitas kemanusiaan yang relatif. Petunjuk konkret untuk memupuk persaudaraan menurut Nurcholish adalah, supaya suatu kelompok dari kalangan orang-orang beriman tidak memandang rendah atau meremehkan orang dan agama lain.

Oleh sebab itu salah satu hal yang perlu diperhatikan dalam menciptakan kerukunan antar umat beragama di Indonesia adalah: pertama, perlunya reorientasi pendidikan agama yang berwawasan kerahmatan pada kerukunan umat (rahmatan lil 'alanain); keduc, upaya peningkatan kualitas pendidikan pada masing-masing umat. Pendidikan dimaksud adalah pendidikan yang melahirkan akhlak karimah dengan indikator: adanya sikap jujur, tenggang rasa, dan cinta-kasih antar sesamanya. Bukan pendidikan yang hanya sekadar mengedepankan intelek, tetapi kemudian melahirkan manusia-manusia korup. Reorientasi pendidikan agama di atas sudah saatnya dimulai dari TK hingga perguruan tinggi dengan merubah kurikulum kita selama ini. Di sinilah saya kira perlu dikembangkan sikap apresiatif di antara umat beragama sehingga jauh dari sikap arogansi dan saling membenci ai antara mereka.

\section{Horizon Baru Kajian Islam Di Indonesia: Masih Ada Secercah Harapan}

Seiring dengan perkembangan pemikiran Islam di Indonesia, kita masih memiliki harapan akan lahirnya perubahan yang menggembirakan. Di kalangan akademisi dan intelektual kita, kini telah muncul "kesadaran baru" bagi tumbuh dan berkembangnya pemikiran terbuka (inklusif) dalam pemahaman agama. Munculnya pemikiran intelektual Islam transformatif, liberal, inklusif, kontekstual, dan apa pun istilahnya merupakan era baru bagi desakralisasi pemikiran Islam (alla taqdisiyyah). Apalagi kemudian pemikiran-pemikiran kontemporer liberalinklusif seperti Hassan Hanafi, Arkoun, al-Jabiri, al-Naim dan seterusnya telah disosialisasikan oleh generasi intelektual muda di Indonesia. Ini memang merupakan keniscayaan (natural). Munculnya mata kuliah yang relatif baru, yaitu Metodologi Studi Islam (Islam Wissenschaft) di Perguruan Tinggi Islam juga pertanda adanya "kesadaran baru" dimaksud.

Ditengarai, bahwa kajian Islam yang adaselama ini belum mampu berkembang seperti halnya kajian-kajian ilmu sosial. Kenapa ini terjadi? Setidaknya ada tiga faktor yang menjadikan model kajian Islam berwatak statis dan tertinggal: pertama, subject matter kajian Islam masih berorientasi ke masa lalu dan bersifat normatif serta tekstual.; kedua, masih mengentalnya sistem pengajaran maintenance learning yang bercirikan lamban, pasif dan menganggap selalu benar terhadap warisan masa lalu; ketiga masih ada pandangan dikotomis terhadap ilmu secara 
substansial (ilmu agama dan ilmu umum). Namun, ini bukan berarti bahwa kita harus meninggalkan semua warisan masa lalu. Warisan masa lalu sangat berharga nilainya karena ia merupakan mata rantai sejarah yang tidak boleh diabaikan. Prinsipnya: kita tetap memelihara tradisi warisan masa lalu yang baik dan mengambil tradisi yang lebih baik (al-muhafadhat ala "l-Qadim as-Shalih wa 'l-akhdzu bi 'l-Jadid al-Ashlah).

Secara umum Johan Hedrik Meuleman (2002: 16-17) melihat adanya beberapa kelemahan tradisi ilmiah di kalangan Muslim, yaitu pertama, adanya logosentrisme, tektualis. Akibat logosentrisme tersebut kemudian mengabaikan unsur tak tertulis dari agama dan kebudayaan Islam, seperti tindakan sosial, seni dst.; kedua sikap apologetik terhadap aliran (teologi, figh dst.); ketiga adanya kecenderungan yang verbalistik dan memberikan wibawa terlalu besar pada tradisi, yang berimplikasi pada sikap ekskulisivisme. Kondisi demikian menurut Meuleman, bebannya masih terasa sampai sekarang ini. Malangnya hal serupa juga dialami oleh Islamolog Barat.

Menurut ST. Sunardi (2000: 79), kajian Islam kini hendaknya mampu mendorong untuk menegakkan keadilan. Semangat pos-kolonialisme bisa menjadi inspirasi bagi kajian Islam, karena pos-kolonialisme mempersoalkan langsung produksi pengetahuan (wacana ilmiah) pada level global. Menurut Sunardi, jika tidak mampu menyentuh persoalan ini, maka kajian Islam tidak lebih daripada kelanjutan dari neo-orientalisme. Perlu dipertimbangkan pula pentingnya kajian Islam untuk menjadi bagian - baik secara langsung maupun tidak- dari gerakan sosialkeagamaan yang plural. Oleh sebab itu, kajian Islam tidak bisa dilepaskan dari konteks sosialnya.

Kini, menurut Muslim Abdurrahman (2003: 6), di kalangan NGO's Islam telah terbuka terhadap masuknya dua corak pemikiran kritis sekaligus, yaitu tradisi pemikiran kritis ilmu-ilmu sosial (seperti Gramsci, Freire) dan tradisi kritis pemikiran Islam (seperti Hassan Hanafi, Arkoun dst.). Perjumpaan ilmu-ilmu sosial kritis dengan wawasan keislaman kritis sejak tahun '90-an memang merupakan fenomena yang menarik di kalangan NGO's Islam. Hal ini bersamaan dengan tumbuhnya keasadarantentang pentingnya "civil Islam" dalam demokrasi sekarang. Oleh sebab itu, hubungan antara ilmu-ilmu sosial yang "memihak" dengan teologi Islam yang "memihak" terhadap proses "pemerdekaan" dalam rangka otonomi sosial, menurut Muslim, menjadi wacana yang ramai dibicarakan di mana-mana.

Di sinilah maka ST. Sunardi menyarankan perlunya kajian Islam yang berorientasi pada demokratisasi, yaitu mengeliminasi kesenjangan kekayaan dan kekuasaan. Dengan demikian kajian Islam bisa berfungsi ganda, yaitu melakukan otokritik atas kajian Islam (modern) yang ada, dan kritik atas demokrasi. Dalam konteks ini menurut ST. Sunardi (2000: 78), kajian Islam dapat dilihat sebagai ilmu sosial kemanusiaan dengan fungsinya yang terus-menerus dapat diperdebatkan.

Perkembangan studi Islam di Indonesia nampaknya menjanjikan masa depan 
yang menggembirakan, sebab jika dilihat dari watak dasamya, Islam adalah agama yang terbuka. Oleh sebab perkembangan semacam ini secara akademik akan menjanjikan. Karena itulah rekonstruksi Islam di Indonesia sebagai objek kajian, akan lebih banyak didominasi oleh ilmuwan Islam sendiri, yang kebanyakan mereka telah melakukan dekonstruksi orientalism -yang menekankan watak konservatif, statis dengan disiplin filologi yangketat—menjadi lebih empiris, reflektif dan humanis.

\section{E. Kesimpulan}

Pluralisme merupakan kenyataan sejarah yang tidak bisa diingkari keberadaannya, dan merupakan tantangan yang dihadapi oleh agama-agama dunia dewasa ini. Untuk menghadapi tantangan pluralisme, diperlukan pemahaman yang plural terhadap agama. Setiap agama hendaknya dinilai sebagai tradisi-tradisi yang utuh, bukan sebagai fenomena keagamaan yang partikular. Tradisi perbedaan keagamaan hendaknya dianggap sebagai sama-sama produktif (equallyproductive) dalam mengubah manusia dari perhatian pada diri sendiri (SelfCentredness) menuju perhatian pada Tuhan (Reality-Centredness).

Semua agama cenderung memiliki klaim absolutisme, baik Islam, Kristen Hindu maupun Yahudi. Klaim pemeluk agama monoteisme yang partikularistk-subjektif akan berdampak pada konflik antarumat beragama, dan konflik tersebut akan menjadi memuncak jika beberapa organisasi keagamaan yang kuat dan partikularistik hidup berdampingan.

Tidak ada agama yang memiliki esensi tunggal. Yang ada adalah perbedaan penafsiran tentang Tuhan: God, Emptiness, Suchness, the One, Nature, the Many. Perbedaan agama-agama hanya berada pada level eksoterieme, sementara pada level esoterisme terdapat titik temu. Kita tidak bisa mengabaikan perbedaanperbedaan yang ada dalam masing-masing agama untuk menarik kesimpulan bahwa "semua harus menjadi satu".

Dalam memahami persoalan agama-agama perlu pendekatan multikultural, dimana pendekatan ini berusaha menjauhkan sikap absolut, subjektif dan ekslusif. Pemahaman ini juga setara dengan pendekatan yang digunakan oleh Schuon dengan istilah esoterisme, atau yang digunakan Hick dengan pendekatan pluralis-nya. Mengedepankan aspek moral dan sosial dalam agama juga diperlukan agar agama tampil sebagai pembawa rahmat bagi semesta alam.

Kita masih memiliki harapan akan lahirnya perubahan yang menggembirakan. Di kalangan akademisi dan intelektual kita, kini telah muncul "kesadaran baru" bagi tumbuh dan berkembangnya pemikiran terbuka (inklusif) dalam pemahaman agama. Munculnya pemikiran intelektual Islam transformatif, liberal, inklusif, kontekstual, dan apa pun istilahnya merupakan era baru bagi desakralisasi pemikiran Islam (alla taqdisiyyah). Apalagi kemudian pemikiran-pemikiran kontemporer 
liberal-inklusif seperti Hassan Hanafi, Arkoun, al-Jabiri, al-Naim dan seterusnya telah disosialisasikan oleh generasi intelektual muda di Indonesia, seperti pemikiran kelompok muda NU, LKiS, JIL-nya Ulil Abshar Abdalla dll. Ini memang merupakan keniscayaan (natural). Munculnya mata kuliah yang relatif baru, yaitu Metodologi Studi Islam (Islam Wissenschaft) di Perguruan Tinggi Islam juga pertanda adanya "kesadaran baru" dimaksud.

\section{DAFTAR PUSTAKA}

Abdurrahman, Muslim 2003.Kajian Islam dalam Perubahan Sosial, makalah disampaikan dalam forum diskusi rutin dosen-dosen STAIN Malang,

Abdurrahman, Muslim (1994) "Keberagamaan di Dalam Alam Pembangunan", dalam Dialog "Bebas" Konflik, Bandung, Pustaka Hidayah.

Andito ed. (1998). Alas Nama Agama: Wacana Dialog Bebas Konflik: Bandung, Pustaka

Coward, Harold (1989). Pluralisme dan Tantangan Agama-Agama. Yogyakarta: Kanisius.

Dean, Thomas, ed. (1985). Religious Pluralism and Truth Essays on CrossCultural Philosophy of Religion. State University of New York.

Depag RI (1995), Al-Qur'an dan Terjemahannya, Jakarta Depag RI.

Fay, Brian (1996). Contemporary Philosophy' of Social Science. Oxford: Blackwell Publisher.

Hick, John (1985). Problem of Religious Pluralism. London: The Macmillan Press. Horton dan Chester L. Hunt (1993: 304),

Johan Hedrik Meuleman (2002: 16-17)

Jurnal GERBANG, Oktober-Januari, 2002-2003.

Jurnal Komunikasi Perguruan Tinggi, Perta, 2002.

Kung, Hans (1998). "Sebuah Model Dialog Kristen-lslam" dalam jurnal Paramadina, Vol 1 No. 1 Desember. Jakarta: Paramadina.

Lyden, John, ed. (1995). Enduring Issues in Religion, San Diego: Greenhaven Press.

Madjid, Nurcholish (1995)..Islam Agama Kemanusiaan, Membangun Tradisi dan Visi Baru Islam Indonesia, Jakarta, Paramadina.

Majid, Nurcholish (1998: 161 162).

Notingham, Elizabeth K. (1985). Agama dan Masyarakar. Terjemahan A. Muis Naharong, Jakarta: Rajawali Press. 
Puspito, OC. Hendro (1984). Sosiologi Agama, Yogyakarta, Kanisius.

QS.34:24-26

Schuon, Frithjof (1984). The transcendent Unity of Religions. Wheston, Illinois: The Theosophical Publishing House.

Shihab, Quraish (1992). Membumikan al-Qur'an, Bandung: Mizan.

Soroush, Abdul Karim (2003). Menggugat Otoritas dan Tradisi Agama, terjemahan Abdullah Ali, Bandung: Mizan.

Stark, Rodey (2003) One True God: Resiko Sejarah Bertuhan Satu, terjemahan M. Sadat Ismail, Yogyakarta: Qalam.

Sumarthana, T.H, "Menuju Dialog Antar Iman", Pengantar dalam Dialog : Kritik dan Identitas Agama, Yogyakarta, Dian/Interfedei, 1995, Seri Dian I/Tahun I.

Sunardi, t.t. Dialog. "Cara Baru Beragama," dalam Dialog: Kritik dan Identitas... Sunardi, ST. (2000)

Tracy, David (1987). Plurality and Ambiguity, Hermeneutic, Religion, Hope. University of Chicago Press.

Zakiyuddin (2002). Ambivelensi Agama, Konflik dan Nirkekerasan. Yogyakarta: Lesfi. 